\title{
RUUMILISE KEELE MEHHANISIMID JA VÕIMALUSED MÕISTE KÄSI VÄLJENDAMISEL
}

\section{Silvi Tenjes}

\begin{abstract}
Ülevaade. Artiklis vaadatakse, milline on mõiste KÄSI väljendite variatiivsus Eesti kultuuriruumis. Eesmärgiks on uurida eestikeelseid fraseoloogilisi väljendeid ja väljendverbe lekseemiga $k a ̈ s i$, et leida, milliseid ruumisuhteid $k a ̈ e$-väljendid representeerivad, kuidas on toimunud metafoorne projektsioon ning milline on sealjuures olnud kohakäändeline representatsioon. Uurimistöö teoreetiline raamistus on seotud S. C. Levinsoni seisukohtadega keelest ja kultuurist (Levinson 2000, 2001) ning C. Sinha käsitlustega inimese sümboliseerimisvõimest, tema kultuurilis-kognitiivsetest skeemidest ning inimese bioloogilisest ja kultuurilisest arengust (Sinha 1999, Sinha, Jensen de López 2000), samuti G. Lakoffi ja M. Johnsoni metafooriteooriaga (1980). Vaadatakse ka tähenduse grammatisatsiooni seoses sõna käsi kohakäändeliste fraasidega. Artiklis on esile toodud varasemaid somaatilise sõnavara uuringuid ning näidatud kaasaegsete seisukohtade seost eelnevatega.*
\end{abstract}

Võtmesõnad: kognitiivne lingvistika, semantika, metafoorsus, ruumigrammatika, keel ja kultuur, eesti keel

\section{Sissejuhatus}

Olen uurinud käežestide ja kõne seoseid nii ruumis viitamise (Tenjes 2003a) kui metafoorsuse seisukohast (Tenjes 2004). Siinses uurimuses vaatan, milline on mõiste KÄSI väljendite variatiivsus Eesti kultuuriruumis. Eesmärgiks on uurida eestikeelseid fraseoloogilisi väljendeid ja väljendverbe lekseemiga käsi, et leida, milliseid ruumisuhteid käe-väljendid representeerivad, kuidas on toimunud metafoorne projektsioon ning milline on sealjuures olnud kohakäändeline representatsioon. Uuringud on alles töös.

* Käesolev uurimus on võimalik tänu Eesti Teadusfondi grandile nr 5519. Olen tänulik kahele anonüümsele 
Erinevalt teistest olenditest saab inimene kõnelda, muuhulgas ka ruumist. Ruumiline keelekasutus on inimkeeltele omane. Eesti keeles sageli ei tajuta enam varasemaid otseseid tähendusi, mis on aja kulgedes grammatiseerunud, muutunud abstraktsemaks või toonud algsest tähendusest tänapäeva vaid osa oma tähendusest. Ruumisuhted võivad keeles olla väljendatud orientatsiooni kaudu suund inimese kehast eemale või keha poole. Selle aluseks on idee kohaväljendite arengust konkreetsemalt abstraktsemale. Eelnevaga on seotud antropomorfsuse printsiip, mis idee tasandil töötab just nagu ruumisuhe, kuid võib olla veelgi vanem kui maailma mõistestamine oma keha järgi: elututele asjadele inimlike omaduste andmine võis eelneda ruumisuhetele keeles, mistõttu enne ruumisuhteid võiks käsitleda antropomorfsust. Ruumisuhete väljendamine (eesti) keeles kuulub ka grammatisatsiooniteooria valdkonda ning väljendub eelkõige kohakäänete tekkimises. Metafoorsus kui ülekandemehhanism võib töötada nii ruumi mõistestamisel kui antropomorfsuse esiletoomisel. Kehaosade nimetuste metafoorne kasutus võib põhineda elutu eseme mingile osale viitamisel või väljenduda inimkeha kasutamisel ruumi kujutamise mudelina.

Uurimistöö teoreetiline raamistus on teistehulgas seotud Stephen C. Levinsoni seisukohtadega keelest ja kultuurist (nt Levinson 2000, 2001) ning Chris Sinha käsitlustega inimese sümboliseerimisvõimest, tema kultuurilis-kognitiivsetest skeemidest ning bioloogilisest ja kultuurilisest arengust (Sinha 1999, Sinha, Jensen de López 2000), samuti George Lakoffi ja Mark Johnsoni metafooriteooriaga (1980). Vaatan põgusalt ka tähenduse grammatiseerumist sõna käsi kohakäändelistes fraasides. Selles osas olen kasutanud Helle Metslangi (2002) ja Krista Ojutkangase (2001) uurimusi. Artiklis on esile toodud ka varasemaid somaatilise sõnavara uurimusi ning näidatud kaasaegsete seisukohtade seost eelnevatega.

\section{Teoreetilised alused}

\subsection{Tähenduse dünaamilisus}

Kognitiivistika kui inimese meelte, taju ja mõtlemise uurimine ei tähenda kitsalt kognitiivset grammatikat ega isegi kognitiivset keeleteadust. Kognitiiv-funktsionaalne keeleteadus tahab ühendada parima varasemast, nüüdseks klassikalisest strukturalismist, ning otsib koostööd kognitiivteaduste kõige viljakamate osadega, et seletada keelt. S. C. Levinson (2000, 2001) käsitleb keeleuurimise võimalusi bioloogia ja kultuuri interaktsioonis. Keel ja inimloomus näivad lahutamatult kokku kuuluvat. S. Levinson ütleb, et üle kahe ja poole tuhande aasta on Lääne intellektuaalne traditsioon kõikunud vaadete vahel kas keel on inimloomuse või inimkultuuri oluline osa ning meil pole kindalt vastust tänagi. Ilmselt see polegi üheselt vastatav.

Me pole senini leidnud rahuldavat teed, et ületada vana väsinud loomuseomandamise (ingl Nature-Nurture) ${ }^{2}$ teemat. Selle vastuse on sõnastanud oma raamatus Elman jt: "Vastus ei ole mitte loomus võ i omandamine, vaid loomus ja omandamine. Muidu tähendaks see püüdu ühte välja mängida teise vastu, kuid tegelikult on oluline mõista nende omavahelise interaktsiooni loomust." (Elman jt 1996: 357) Käesoleval pendlivõnkel on keeletea-

2 nature-loodus; loomus, olemus, natuur; liik, sort (Silvet 1990: 44).

nurture - üleskasvatamine, kasvatus, hoolitsus; toitmine, toit (Silvet 1990: 69). 
dus loomuse poolel - keelt on sageli käsitletud kui instinkti (Pinker 1994, Gopnik 1997, kuid vaata Tomasello 1995). Kuid selleks, et ületada pendli see võnkepool, peame me leidma uue raamistiku, mis suunab meie uurimused keeles eriomasesse interaktsiooni bioloogia ja kultuuri vahel. ${ }^{3}$ (Levinson 2000: 258)

S. Levinson kritiseerib Noam Chomsky ja tema järgijate väidet, et keel on lihtsalt universaalsete sisemiste mentaalsete struktuuride projektsioon. S. Levinson ütleb, et "lihtne sünnipärasus" näib vältimatult eeldavat evolutsioonilist vaatenurka. Kuid N. Chomsky ise lükkab otsustavalt tagasi idee, et meie kaasasündinud keelelised võimed on "lahti hargnenud" (ingl evolve) kohanemisvõimeliste joontena. Seega näib N. Chomsky arvavat, et ta on leidnud sügavad, aluseksolevad, eriti keerulised kitsendused, mis on mitmes suhtes kohanemisvõimetud - st nad teevad lausete grammatilise analüüsi (ingl parsing) raskeks. Sellest järeldub kohanemisvõime loodusliku valiku suuna teatud ümberpööratus: inimesega seoses ei vaja kohanemisvõime strateegiad geneetilist toestamist, ainult kohanemisvõimetutel on seda vaja! Sellest ka N. Chomsky huvi süntaksi keeruliste detailide vastu ja usk, et need ongi kohanemisvõimetud mustrid, mis on aluseks keele kaasasündinud loomusele. S. Levinson ütleb muuhulgas, et sellise strateegiaga ignoreeritakse või minimeeritakse keelte ja kultuuride vahelisi väga olulisi erinevusi. "Meid ehitatakse käsitlema mitmesugusust (ingl diversity): keel on biokultuuriline hübriid." (Levinson 2000: 260)

C. Sinha on arendanud ideed bioloogilisel alusel rajaneva ruumi kognitiivsusest, mis hõlmab endas kultuuriliselt kindla materjali ja lõimub keelelises praktikas. Ruumi kognitiivsus on inimesse kehastunud ja bioloogiliselt evolutsiooni käigus arenenud inimese võime kolmemõõtmelises ruumis hakkama saada. Eriti oluline oli püstiasend, nii keele kui meele jaoks. Inimese kognitiivsus - tema meeled - on lõimunud kultuuri ja keelde. Kognitiivlingvistika oluline hüpotees on, et "tähendus on motiveeritud projitseerimine mõistestamisest väljendisse" (Sinha 1999: 227). Tähendused ei ole objektid, vaid "aktid", "tegevused" (nii kõneakti mõttes kui üldisemalt). Lingvistiline tähendus on sotsiaalne "tegevus", mis viiakse lõpule subjektidevaheliselt, tähendus pole asi. Nii et mõistestamine on aktiivne protsess. Me mõistestame keeles (mitte keelt) ja teeme seda selleks, et osutada millelegi, kuhugi, kellelegi. C. Sinha selgitab uut seisukohta, et tähendus on dünaamiliselt mõistetav; projitseeriv suhe või seos lingvistiliselt mõistestatud osutava situatsiooni ja kontseptuaalselt motiveeritud väljendi vahel (Sinha 1999: 231). Dünaamiline tähendus peaks siis hõlmama grammatiseerunud tähenduse ja metafoorse tähenduse. C. Sinha ja Kristine Jensen de López toovad oma artiklis (2000: 23) näite kehaosade tähendusest seoses inimese algsete arusaamadega inimkehast ja maailmast. Näiteks on Põhja-Ameerika Coeur d'Alene'i indiaanlastel ${ }^{4}$ sõna, mis tähistab käeselga (st käe SELG, käe tagapool, ingl back of the hand), mis eesti keeles on tähistatud sõnaga käeselg.

\footnotetext{
${ }^{3}$ S. Tenjese esiletõst.

${ }^{4}$ Hõimuliikmed nimetavad end muistses hõimukeeles olnud nimetusega schitsu'umsh' tähenduses 'need, kes leitakse siin' või 'avastatud rahvas'.
} 


\subsection{Tähendus ja grammatiseerumine}

Aglutineerivatele keeltele on omane sufiksite suur hulk ja sõnamoodustussüsteemi rikkus. Sellest on kirjutanud kehaosade mõistete grammatiseerumist käsitlevas töös K. Ojutkangas. Sõnamoodustussufiksid on grammatilised üksused, mille teke kuulub grammatiseerumise valdkonda, kuid nende kasutus tekitab uusi üksusi leksikasse, mitte grammatikasse (Ojutkangas 2001: 80-82). K. Ojutkangase töö rõhk on grammatiseerumisel, kuid ta arutleb laiemalt ka tähenduse üle, viidates Raimo Anttila seisukohtadele. Keelemuutused ei sünni mitte isolatsioonis, vaid terviku osana. Tähenduselt sarnased sõnad mõjutavad üksteist ja uusi tähendusi. Sõnade eri tähenduste vahelisi suhteid ei saa kujutada lineaarsena. Tegemist on pigem võrgustikuga, kus sõna tähendust mõjutavad (assotsiatiivsed) tegurid on mitmesuunalised ja ristuvad. Võrgustikus võib üks tähendus hõivata rohkem kui ühe sõlmpunkti (Anttila 1974: 336, viidatud Ojutkangas 2001: 37 järgi). Keeleväljendite moodustatud võrgustik on dünaamiline ja paindlik ning üksuse iga kasutusjuhtum võib mõjutada võrgustiku sisu ja struktuuri. See on semantiliste väljade teooria edasiarendus, kuid siingi on öeldud, et tähendus on dünaamiline. Sellist võrgustikku võib märgata ka eesti sõna käsi puhul, mis on andnud abstraktsed verbid käsitama - 1. 'aru saama', 'mõistma', 'taipama'; 'midagi teatud viisil tõlgendama'; 2. 'rakendama', 'tarvitama'; käsitlema - 1. 'teatud küsimuse või ainega tegelema', 'tegemist tegema'; 'midagi kõne, vaatluse alla võtma', 'arutama'; 2. 'rakendama', 'tarvitama'; 3. 'keemiliselt mõjutama'.5 Keelelise väljendi tähendust ja käitumist mõjutavad nii kõneleja lingvistilised kui ka entsüklopeedilised teadmised. Sõna semantilist muutust mõjutab kogu keele kultuuriline situatsioon.

Eesti keeles on grammatisatsiooniteooriast ülevaatlikult kirjutanud H. Metslang (2002). Rääkides tähendusnihkest kui grammatiseerumise käivitajast ütleb ta, et tähendusnihkeks võib olla "metonüümia (nt sõna käsi baasil pars pro toto abil kujunenud kaassõna: minu käes 'minu valduses')." (Metslang 2002: 166) Grammatiseerumine ei ole siiski kõikehõlmav keelemuutuste analüüsi- ja seletusmall. Ka H. Metslang toob grammatisatsiooni piiridest rääkides

.. vastunäiteid grammatikalisatsiooni ühesuunalisusele: tavaline muutumissuund on küll leksikaalsest grammatiliseks vahendiks, üksikutel juhtudel võib aga ka grammatikavahend muutuda leksikaalseks (nagu eesti $e b a$, ism, aga - liited ja abisõnad, mida kasutatakse ka nimisõnadena). (Metslang 2002: 173)

Keeles ja mõtlemises ilmneb järgnevas osas käsitlemisele tulevast metafoorist palju laiemalt suund füüsiliselt mentaalsele, mis on ka diakrooniliste tähendusmuutuste alusideeks (nt Sweetser 1995). Keeleväljendite arengus ruumilisest abstraktsemasse avaldub juba Eve E. Sweetseri poolt esile toodud sõnatähenduse muutuse kindel suund ajaloolises arengus.

H. Metslang on eesti keele grammatisatsiooni kuldnäiteks toonud komitatiivi kujunemise (muutuste järjend (1) pärineb Huno Rätsepalt 1979: 77-78, viidatud Metslang 2002: 164 järgi):

(1) kansak > kāsak > kāsa? > kās > kas > -ka > -Ga

${ }^{5}$ Mõistete seletused pärinevad "Eesti kirjakeele seletussõnaraamatust" (EKSS). 
H. Metslang selgitab, et "muutus toimus paari sajandi jooksul, sellest annavad tunnistust vana kirjakeele näited nagu 16. sajandi Ißantswkas Kullamaa käsikirjas, 17. sajandist Sannade kahs Mülleril, herje kaa Gösekenil.” (Metslang 2002: 164) H. Rätsep on eesti keele ajaloolise morfoloogia töös käsitlenud $G a$-lõpulise komitatiivi tekkimist häälikumuutuste kaudu põhjalikult:

Ga-lõpulise komitatiivi tekkimine on seotud kaassõnaliste väljendusviiside levimisega läänemeresoome varasemal perioodil. Substantiivist kansa moodustati $k$-latiivivorm *kansak, mida hakati kasutama postpositsioonina koos genitiivis põhisõnaga. Seega esialgu olid ühendid *jalyan kansak,

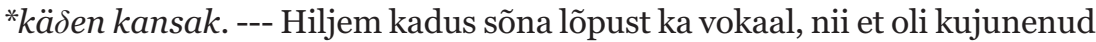
sõna kaas. (Rätsep 1979: 77-78)

Arhailise adverbi/postpositsiooni *kansak grammatiseerumise käändelõpuks võis põhjustada sõna käsi genitiivivormis põhisõnana ning võib jälgida sõna käsi juurde kuuluva vormi käekäiku muutusteahelas (2).

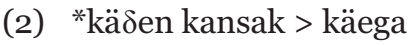

\subsection{Metaforisatsioon ja ruumi mõistestamine}

G. Lakoffi ja M. Johnsoni järgi (1980) on metafoor keele ja mõtlemise, inimliku loovuse põhivorm. Metafoor ja metonüümia on maailma kategoriseerimise põhivahendid. Metafoor ei puuduta ainult keelt, vaid (samavõrd või esmajoones) ka meelt ja mõtlemist. Ta on süstemaatiline viis mõtestada ühtesid kogemusvaldkondi teiste valdkondade kategooriates ja terminites. Vastavalt G. Lakoffi ja M. Johnsoni metafoorikäsitlusele moodustatakse abstraktsed mõisted süstemaatiliselt konkreetsetest metafoorse ülekande teel. Kui neid abstraktseid mõisteid vastavalt G. Lakoffile ja M. Johnsonile nimetada kontseptuaalseteks metafoorideks, siis teatud piirideni toimivad nad tõesti kui kindlad abstraktsioonid (ARMASTUS ON TEEKOND, INIMESED ON LOOMAD), aga ei seleta paljusid muid keelt muutumises hoidvaid mehhanisme. Metaforisatsioonist kui ülekandemehhanismist tähenduse dünaamilisuse esiletoojana on räägitud ka palju varasemates töödes kui G. Lakoffi ja M. Johnsoni oma. Metaforisatsiooni dünaamika tuleb esile juba Ivor Armstrong Richardsi 1936. aasta raamatus "Retoorika filosoofia”. I. A. Richards (1965) väidab, et metafoori loodud tähendus on avatud, mitte üksnes selle osade summa. Metafoori moodustamise käigus tekib kahe mõistevaldkonna segamise tulemusena dünaamiline semantiline vastastiktoime, mis säilitab kummagi valdkonna omadused, ent millel on lisaks omaenda unikaalsed omadused. Metaforisatsiooni kaudu saab vaadelda olulist osa keeles toimunud grammatiseerumisest. Metafoorsed projektsioonid on asümmeetrilised põhisuunaga "kehast eemale meele poole" (ingl from body to mind). Siinkohal on põhjust viidata Urmas Sutropi artiklis "Eesti keele maailmapildist: meel, hing ja vaim” esitatud ingliskeelse sõna mind tõlkimisele eesti meeleks.

Meel kajastab õieti juba vanemat, ununema kippuvat maailmapilti. H. Õimu arvates puudub tänapäeva eesti keeles mõiste, mis vastaks inglise sõnale 
mind. Muistne meel oma hajunud tähenduste ja ajaloolise taustaga vastaks sellele aga väga hästi. (Sutrop 2004: 101)

Arutlused, millise eestikeelse sõnaga tõlkida $M I N D$, on sama vanad kui sõna mind ilmumine humanitaar- ja sotsiaalteaduslike tekstide kaudu Eesti kultuuriruumi. Väga üldistatult võin öelda, et psühholoogid pigem tõlgivad igal konkreetsel juhul erinevalt, sagedasemad variandid on vaim, psüühika, meel, filoloogid on tõlkinud seda vastavalt kontekstile kord mõistuseks, kord meeleks jm. Artikli kirjutamise ajaks osutus eesti meel minu jaoks ka taas kord sobivaks tõlkevasteks.

Keeles toimib ka eelnevalt nimetatud füüsiliselt mentaalsele vastassuunaline vool: antropomorfisatsioon (personifikatsioon), mis on samas ka kui kahesuunaliselt toimiv mehhanism: elutute asjade inimestamine annab neile just nagu meele ja tahte, abstraktsete ja mentaalsete asjade personifikatsioon annab neile ühtlasi "keha". Piltlikult öeldes võivad keeleväljendid siis "minna" taas ruumisuhete tasandile ning grammatiseeruda, nagu juba eelnevalt öeldud. Eesti keeles on seda teemat käsitlenud Uku Masing juba 1930. aastatel. Sel ajal oli humanitaarteadustes oluline mõiste psühholoogia, nii nagu praegu on peaaegu kõik kognitiiune. U. Masing käsitleb eesti keele psühholoogiast rääkides muuhulgas mõistet käsi. Ta ütleb:

Iga eestlane arvab, et ta teab, mis "käsi" tähendab. .. Muidugi ta ütleb, et käsi on üks osa kehast. Aga talle ei tule meeldegi eesti keelele tüüpilised väljendid, mida ta tarvitab iga päev, nagu: külma käes, tuule käes, päeva kätte, koerte kätte, käest kaduma, mitmekesi (mitme+käsi). (Masing 1993: 52)

Kui mõtleme, et tuulel või päiksel on käed, on meil tegemist antropomorfismiga. Tõeliselt ilus leid on aga U. Masingul mitmekesi, kus mina poleks sõna käsi näinud. ${ }^{6}$

Mõistega KÄSI seotud väljendite käsitlemisel olen vaadanud, kuidas käituvad fraasid kontseptualisatsiooniprotsessis. Me oleme oma kognitiivse loomusega kasvanud sedavõrd sügavalt ja laialt oma kultuurilisse ruumi sisse, et ülekannete aluseks olevaid allikalasid on väga raske tuvastada. Mõisted, mis toovad esile teatud ajal minevikus konkreetset sõnasõnaliselt mõistetud tähendust, muutuvad aja jooksul ja kultuuriruumi teisenedes sageli metafoorseteks, nagu oleks liiga kulunud väljendile vaja "uut nägu” (Tenjes 2002b: 5). Tähendusmuutused kujunevad üldiste ülekandeprintsiipide järgi, kus metaforisatsioon võib olla üks põhilisimaid võtteid. KÄEGA seotud väljendite muutusi tähistavaks ülekandeprintsiibiks võiks olla järgmine rida:

(3) nähtus $\rightarrow$ ruum $\rightarrow$ metaforisatsioon $\rightarrow$ sotsiaalsed suhted

Ruumisuhted, mis keeleliselt võivad leida kajastamist somaatilises sõnavaras, tuginevad inimese füüsilise ruumi tajumisele kolmel teljel: vertikaalsel, horisontaalsel ja lateraalsel. Vertikaalne telg ÜLEVAL-ALL ei ole määratud otseselt inimese keha, vaid füüsikaseaduste, maa külgetõmbejõu poolt. Horisontaalne telg EES-TAGA on aga otseselt seotud inimese kehaehitusega, samuti lateraalne telg VASAK-PAREM, mis sünnib ka inimese kehalise kogemuse kaudu. Inimkeha kolmest tähtsamast piirkonnast, milleks on pea, kere ja jäsemed, on viimane

${ }^{6}$ Tänan Lembit Vaba, kes juhtis tähelepanu sellele, et - kesi on kujunenud substantiivi kesk pluurali instruktiivi vormist. Minule meeldib U. Masingu etümoloogia ja jään selle juurde. 
ruumilise orientatsiooni allikana peaaegu tähtsusetu (Svorou 1993: 70-71). See ärgitab vaatlema $\mathrm{KÄE}$ positsiooni eesti keeleaineses.

KÄE-fraaside ja käežestide uurimine lubab arvata, et käe roll keele tähendussfääris ei ole võrreldav teiste kehaosade rolliga keeles ja kultuuris, inimese kognitsioonis. Mõiste KÄSI metafoorsed projektsioonid ruumilisest valdkonnast sotsiaalsemasse (abstraktsemasse) valdkonda ei pruugi toimuda sellises ulatuses kui mõistete PEA või JALG puhul. Ilmselt ülalnimetatud põhjustel pole ma ka kohanud, et mõistet KÄSI oleks süstemaatiliselt käsitletud ruumiliste mõistete kontseptualiseerimist käsitlevates töödes. Käel on igapäevane otsene roll inimese tegevustes ning see väljendub ka keeles. Nii võivad ruumilised suhted konkreetsest abstraktsemasse selles valdkonnas olla kõige piiratumad. Tundub, et seetõttu ei paku KÄSI huvi nendele kognitiivlingvistidele, kes püüavad leida näiteid oma seisukoha tõestuseks sealt, kus neid rohkem leida on (selle kohta ja ka holistilisest ning modulaarsest kognitiivsest lingvistikast vt Tenjes 2003b). Käe primaarses füüsilises kasutuses avaldub aga inimese nii kognitiivne sättumus kui kultuuriline seotus.

\section{KÄSI ajaloolises keeleteaduses}

Küsimus, millele esmapilgul tahaks vastust leida, võiks olla Kui kaugele ajas läheb tagasi mõiste KÄSI?, kuid tegelikult ei anna küsimuse ainult diakrooniale suunatud püstitus midagi konstruktiivset. Iga keel on alati muutumises, ja võiks hoopis küsida Miks on antud keeles just nïmoodi väljendatud? Mida ühe või teise mõiste kontseptualiseerimisvõimalused ütlevad seda keelt kõnelenud rahva kultuurimälu ja kontaktide kohta teiste rahvastega? Just nendes küsimustes saavad kokku kognitiivne ja kultuuriline. Sotsiokultuurilised muutused peegelduvadki keeles, peegelduvad selles, mida inimesed on pidanud mõistestama ja kuidas nad on seda teinud. Näiteks juba eesti muistsete, III aastatuhandest e.m.a pärinevate liittüveliste ja tuletuslike isikunimede uurimustest (Roos 1976) nähtub muuhulgas, et kehaosadest on produktiivsed olnud pea ja jalg (nt nimed Hawapee, Raudjalg), aga mitte käsi. Samasugust produktiivsust kinnitab ka K. Ojutkangase kehaosade nimetuste grammatisatsiooni uurimus (Ojutkangas 2001). K. Ojutkangas märgib, et konkreetse mõiste laiendus abstraktsesse sfääri tuleb rohkem esile mõiste PEA puhul. Ajaloolisele keeleteadusele vastavalt ulatuvad soome-ugri keelte andmed tagasi isegi kuni 8000 aastat.

Soome-ugri tüvede rühma kuuluvad sõnatüved, millel on sugulasvasteid vähemalt ühes ugri (mansi, handi või ungari) keeles, kuid samojeedi keeltes mitte. Nendel tüvedel on vanust vähemalt 5000 aastat, sest nad olid olemas juba soome-ugri algkeeles. Soome-ugri tüvesid on eesti kirjakeeles 179306, s.o. 3,23-5,52\% tüvede koguarvust. Sellesse rühma arvatakse ka sõna käsi. (Rätsep 2002: 63-64)

Seega on käsi ajaloolise keeleteaduse seisukohast soomeugrilise päritoluga ja kaugemale tagasi ei ulatu, samuti pole kerge just selle sõna jaoks leida piisavalt häid etümoloogilisi seoseid indoeuroopa vastavate tüvedega. Seda fakti on autorile kinnitanud ka nimekas fennougrist Tiit-Rein Viitso (isiklik vestlus). "Hõimumurded, 
mille põhjal kujunes hilisem eesti keel, hakkasid läänemeresoome keeleühtsusest silmatorkavalt lahknema alles 2000-2500 aastat tagasi.” (Rätsep 2002: 9)

Eesti keeleuurijatest on Paul Alvre eesti keele morfoloogiat kirjeldades peatunud ka kehaosi märkivate nimetuste arvulisel ebaloogilisusel väljendites kindad käes, sukad jalas jt (Alvre 1989). Õigem oleks ju öelda kindad kätes. Kuid P. Alvre on soome-ugri keelte ajalugu uurides leidnud, et "algselt väljendati paaris-kehaosi (käed, jalad, kõrvad, silmad jt) ainsusliku nimetusega, sest selliseid mõisteid peeti ühtseks tervikuks, paariks, nt käsi tähendas kätepaari e. mõlemat kätt .." (Alvre 1989: 149) P. Alvre väitel olid sedasorti somaatilised fraseologismid konservatiivse iseloomuga ega suutnud kohaneda keele arenemise käigus esilekerkinud uue grammatilise kategooriaga, milleks oli mitmus. Eesti keele obliikvakäänded on suhteliselt hilist päritolu. Seega pidi varasemal ajal ühe käe, jala või kõrva jaoks olema teine väljend ning P. Alvre ütleb, et see oli pool - üht kätt ja jalga nimetati pooleks käeks ja pooleks jalaks. Soome keeles on veel säilinud käsipuoli ühe käega inimese tähenduses. Ruumilise keele esitamine inimeste maailmast arusaamise kaudu saab veelgi mõistetavamaks P. Alvre väite kaudu, et "seesütlev kääne ( $k a ̈ e s$, jalas) varem ei tähendanud ainult sees olemist, vaid ka vahetut lähedust, kontakti käega-kätega, jalaga-jalgadega." (Alvre 1989: 149) Sellest siis ka vormiliselt ainsuslikud väljendid, mis tegelikult väljendavad mitmuslikku sisu, nt kindad on käes, kindaid kätte panema, kindaid käest võtma. Seejärel esitab P. Alvre grammatisatsiooniteooria seisukohalt olulise tõdemuse: "Käesoleval juhul peaaegu polegi enam tegemist substantiivide jalg, käsi jt tavaliste käändevormidega, vaid adverbideks kivinenud sisekohakäänetega.” (Alvre 1989: 150)

\section{Näiteid mõistega KÄSI}

Järgnevalt esitan mõned näited mõistega KÄSI seotud fraseoloogilistest väljenditest ja väljendverbidest, et jälgida neis metafoorse ülekande, kohakäändelise representatsiooni ja antropomorfsuse esiletulekut. Vaadeldavad mõistega KÄSI seotud andmed pärinevad eesti keele püsiühendite andmebaasist. ${ }^{7}$ Püsiühendite andmebaasis on 20794 kirjet, millest fraasiverbide andmebaas sisaldab 17493 kirjet ning väljendite andmebaas 3301 kirjet. Antud uurimuses on kasutatud mõistega KÄSI seotud väljendeid, mida fraasiverbide andmebaasis oli 224 kirjet ja väljendite andmebaasis 102 kirjet.

Nagu juba öeldud, ei moodusta KÄSI nii aktiivselt ruumimõisteid kui mõisted PEA ja JALG (Ojutkangas 2001). Mõistega KÄSI seotud väljendites ilmneb arhailine kehaline alus ning väljendid projitseerivad algseid arusaamu, nagu näidetes $(5-6){ }^{8}$

(5) Ta võttis lapse käekõrvale.

(6) Naine ringutas meeleheites käsi. ('naine ahastas, naine oli ahastuses') ${ }^{9}$

Antropomorfne (kõrv (näide 5)) ülekandemehhanism kinnitab K. Ojutkangase (2001) samasisulist seisukohta. Käesoleva artikli seisukohalt olulises ja teemat toetavas artiklis ajakirjas Pragmatics \& Cognition käsitleb neid küsimusi Eva

\footnotetext{
7 Autor on tänulik Tartu Ülikooli arvutuslingvistika uurimisgrupile võimaluse eest kasutada eesti keele püsiühendite andmebaasi (http://www.cl.ut.ee/). Andmed pärinevad aastast 2003.

${ }^{8}$ Artikli mahtu arvestades olen mitmed temaatiliselt sobivad näited välja jätnud, sh nt oma käe peal omal 
Lindström, kes oma uurimuses kuoti keele võimalustest emotsioonide väljendamisel kehaosi tähistavate noomenite kaudu on üsna ootamatult artiklis toonud näiteid eesti keelest. E. Lindström seob analoogselt siinkirjutajale aluseks olevate kehaosade noomenite kasutusnihke (antropomorfismi) ja tänapäevased kohakäändelised võimalused (grammatisatsiooni). Tähendusnihet tänapäeva keelekasutaja üldjuhul ei taju. E. Lindström ütleb:

.. väljendi kasutus ja kõneleja tajumused keeles tuleb arvesse võtta enne, kui keeleteadlane rakendab oma interpretatsiooni. Et seda illustreerida, tahaksin tuua eestikeelse näite, kus kehaosa väljendid ja mõned muud noomenid on grammatiseerunud postpositsioonideks. On mitmeid kohakäändeid, mida võib laialt kirjeldada 'sees'-kogumi ja 'pind'-kogumi terminites, igaühel neist on kolm mõõdet: KUST, KUS ja KUHU. ${ }^{10}$ Teisisõnu, ainuüksi käänetega on võimalik näidata selliseid erinevusi nagu '(selle) seest' vs. '(selle) peale' jne. Kuid rahvapärasest kõnest seda küll ei leia, kuidas kääne üksinda niisugust informatsiooni näitab. Selle asemel, et kasutada .. laua-le .. ja .. laual-lt .. on meil tavalised konstruktsioonid .. laua pea-le .. ja .. laua kõrva-le .. Samasuguseid konstruktsioone võib leida näiteks tüvedega juur, äär, pool ja käsi .. Huvitav on see, et eesti keelt emakeelena kõnelejad on täiesti unustanud tõsiasja, et need on samad sõnad. Isegi kui küsida, kas adverbil peal on midagi pistmist sõnaga pea, mõtleb kõneleja veidi ja ütleb seejärel Ei, ma ei arva, ning ainult siis, kui kõnelejad panna vastamisi sellise sõnadekogumiga tervikuna, tunnevad nad mustrid ära. (Lindström 2002: 173-174)

Metafoorne ülekanne ilmneb järgmiste kohakäändelistes väljendites (7-14):

(7) käsile võtma (1. 'millegi kallale asuma, midagi ette võtma, mingi töö või asjaga tõsiselt tegelema hakkama'; 2. 'kedagi tublisti noomima, korrale kutsuma, kellegagi riidlema, kedagi nahutama')

(8) kätte maksma ('arveid õiendama, tagasi tegema, tasuma')

Konkreetne otsene tähendus lausel, nagu (9), võis ollagi tasu andmine ühelt isikult teisele.

(9) Mees maksis kätte.

Väljendi (10) tähenduse järgi võib inimese kätte jõuda nii konkreetne objekt kui ajaline sündmus, nt ülekantud tähenduses pühad (11), reklaamid (12).

(10) kätte jõudma ('saama; pärale jõudma ')

(11) Pühad jõudsid kätte.

(12) Reklaamid tulevad koju kätte.

Pisut modifitseeritud, kuid sisult sarnane tähendus on ka näites (13).

(13) Ta leidis tee kätte.

${ }^{10}$ Siinjuures on sobiv esitada ingliskeelne originaallause: "There are several local cases which can be roughly 
Mõned käe-väljendite lokatiivsed konstruktsioonid võivad realiseeruda adessiivis (14) või elatiivis infinitiiviga (15).

(14) omal käel ('iseseisvalt, kõrvaliste abita või nõuanneteta, omaette')

(15) käest andma ('mingist võimalusest, šansist loobuma')

Kognitiivne aspekt keeleväljendite mõistestamises avaldub eesti keeles eriti väljendites, kus grammatiliselt on olemas illatiiv, kuigi eesti keeles on need sisuliselt väljendverbid või kannavad metafoorset ülekannet ('kätte maksma').

Võrreldes muude $k a ̈ e$-väljenditega, esineb sellistes lokatiivsetes väljendites metafoorset projektsiooni ruumist sotsiaalsesse (abstraktsemasse) valdkonda tunduvalt rohkem kui teiste kohakäändeliste väljendite puhul. Varasemate keeleajalooliste uurimuste ülevaatamise käigus võib tuua võrdluse läti keelega, kus juba 20. sajandi algul on esitatud seisukoht, et eesti ja liivi keel on mõjutanud läti keelt:

Üldse on fraseologismidel, millel sõna käsi on sisekohakäänetes, vähem läti vasteid, sest somaatilise sõna kasutamissfäär (ühendverbides ja postpositsioonidena) ei ole seal nii lai, ka eesti ühendverbiga sarnane verbi ja adverbi (s.o. adverbialiseerunud kohakäände rokā 'käsi') kasutamine on tekkinud eesti ja liivi keele mõjul. (Endzelīns 1906, ${ }^{11}$ viidatud Veinberga 1975 järgi)

\section{Arutlus ja kokkuvõte}

Mõistega KÄSI seotud väljendite esmane uurimine näitab inimese kognitiivset ja kultuurilist seotust (nt tervitus eesti keeles: Kuidas käsi käib?). Eesti keeles (ja paljudes teistes keeltes) on küllalt väljendeid, mis on ühelt poolt žestid, teiselt poolt fraasid ning siin on raskem leida, kas nad on tulnud meie kognitiivsest (loomuslikust) või kultuurilisest taustast. Žeste uurinuna võin oletada, et mitmed käega seotud analoogsed väljendid olid algselt žestid, näiteks lõi kaht kätt kokku, plaksutas käsi, laiutas käsi, kätt südamele panema.

U. Masingu eespool nimetatud eesti keele psühholoogiat käsitlevast artiklist leiame, et käežestidetaolised keeleväljendid olid seotud võimuga.

.. arvestanud mõne muu keele etümoloogiliselt samast tüvest tuletatud sõnadega .. võib olla et ka käskima, kesk, kiskuma, võib enam-vähem kindlalt väita, et "käsi” oli algselt üks neid eesti keeles nii rohkeid sõnu võimu, väe (religiooniloolaste "mana"12) tähistuseks (kehaosade nimed on teatavasti kaunis hilised), eriti selle piirkonna jaoks, kus valitseb kellegi meelevald, mis alistub kellegi jõule. Kui nüüd koguda kõik sõnad, milledega võib "käsi” liituda nimetatud kujul, siis on tulemus see, et eestlaste liikumatuil asjul polnud võimusfääri (päike, nälg, külm olid liikuvad). (Masing 1993: 52)

Nagu eespool viidatud väljendid päeva kätte, tuule käes, külma käes näitavad, pole eestlastel võimu valdajaks olnud isik. Võim oli looduse käes. Inimeste võimu väljendavad käežestid ning nendega seotud vastavad käe-väljendid on liikunud läänepoolsemas kultuuriruumis. Näiteks žest adlocutio (ülestõstetud

\footnotetext{
${ }^{11}$ Tänan toimetaja H. Metslangi, kes juhtis tähelepanu, et samal teemal on töid ilmunud juba märksa varem, nt O. Donner (1884), V. Thomsen (1990).

${ }^{12}$ Küll aga võib samas "helistikus" jätkates püstitada hüpoteesi, et eesti mana on teatud tähendusülekande viisil (üle kantakse nähtuse üks omadus) ladina manus 'käsi', mis omakorda Euroopa kultuuriruumis oli seotud väe ja võimu väljendamisega valitsejatel, nt ladina manus regis oli "'kuninga käsi"', millel olevat vanade uskumuste kohaselt olnud muuhulgas lausa tervendav võime. - S. Tenjese märkus.
} 
käsi), mis on pärit juba etruskide kujukestelt, levis hiljem Roomas ja jõudis sealtkaudu Euroopasse. Žestiga adlocutio kõnetas keiser oma armeed - käe tõstmisega nõudis ta vaikust ja tähelepanu (selle kohta vaata ka "Žestid keskajal", Tenjes 2002a).

Üldistatult võib väita, et võrreldes teiste somaatiliste sõnadega ei tööta KÄSI nii produktiivselt suunal konkreetsemalt abstraktsemale - "kehast eemale meele poole”. Sõna käsi ei moodusta metafoorse ülekande kaudu kaugeltki nii suurt hulka abstraktseid mõisteid kui pea või jalg, ta on "staatilisem", on "keha küljes kinni” ka keeleliselt. Tõsi, sellisena kinnitab ta G. Lakoffi ja M. Johnsoni ideed metafoorist kui keele ja mõtlemise põhivormist ning kuulub pigem konkreetsete mõistete valdkonda, kuid grammatiliste üksuste moodustamine metaforisatsiooni läbi toimub käe vahendusel siiski. Selle väite turvil toimib G. Lakoffi ja M. Johnsoni seisukoht kontseptuaalsetel metafooridel tuginevast kultuurilisest mõtlemisest vähemalt teatud piirides ka eesti keele puhul. Nii on võimalik eestikeelsete käeväljendite kaudu jälgida sotsiokultuurilist kihistust: inimese käelise tegevuse valdkondi, mis on aja kulgedes muutunud ajalooliseks kihistuseks. Samuti on käsi osaline grammatiseerumisprotsessis. Selline muutumine näitab ka tähenduse dünaamilist loomust. Siinjuures pole tähtsusetu märkida, et eesti keel oma lokatiivsete käändelõppudega on suuna kui ruumiomaduse väljendamises palju diferentseeritum kui indoeuroopa keeled.

Kontseptuaalsed e kognitiivsed struktuurid ei kujune maailma lihtsa tunnetamise tulemusena, vaid need omandatakse vastava kultuuri kontekstis teiste inimestega suheldes. Ning keel on siin põhiline vahendaja kultuuriliselt fikseeritud teadmiste ülekandmisel. Seega, tegelikkuse mõistestamine sõltub suurel määral kultuuriruumist, kuhu keel kuulub.

\section{Kirjandus}

Alvre, Paul 1989. Eesti kirja- ja murdekeele morfoloogiat. Eesti NSV Teaduste Akadeemia Emakeele Seltsi toimetised 23. Tallinn: Valgus.

EKSS = Eesti kirjakeele seletussõnaraamat, II köide, 4. vihik. 1993. Eesti Teaduste Akadeemia Keele ja Kirjanduse Instituut. Tallinn.

Lakoff, George; Johnson, Mark 1980. Metaphors We Live By. Chicago: The University of Chicago Press.

Levinson, Stephen C. 2000. Language as nature and language as art. - Changing Concepts of Nature at the Turn of the Millennium. Proceedings of the Plenary Session of the Pontificial Academy of Sciences, 26-29 October 1998. Ed. by Raymond Hide, Jürgen Mittelstrass, Wolf Singer. Series: Pontificae Academiae scientiarum scripta varia 95. Vatican City: Pontificia Academia Scientiarvm, 257-287.

Levinson, Stephen C. 2001. Covariation between spatial language and cognition, and its implications for language learning. - Language Acquisition and Conceptual Development. Ed. by Melissa Bowerman, Stephen C. Levinson. Language, Culture and Cognition 3. Cambridge: Cambridge University Press, 566-588.

Lindström, Eva 2002. The body in expressions of emotion: Kuot. - Pragmatics \& Cognition 10, 1/2, 159-184.

Masing, Uku 1993 [1933]. Hüpoteetilisest eesti keele psühholoogiast. - Vaatlusi maailmale teoloogi seisukohalt. Toim Luule Krikmann. Tartu: Ilmamaa, 51-55.

Metslang, Helle 2002. Grammatikalisatsiooniteooriast eesti keele taustal. - Teoreetiline keeleteadus Eestis. Toim Renate Pajusalu, Ilona Tragel, Tiit Hennoste, Haldur 
Õim. Tartu Ülikooli üldkeeleteaduse õppetooli toimetised 4. Tartu: Tartu Ülikooli Kirjastus, 164-178.

Ojutkangas, Krista 2001. Ruumiinosannimien kieliopillistuminen suomessa ja virossa. Suomalaisen Kirjallisuuden Seuran Toimituksia 845. Helsinki: Suomalaisen Kirjallisuuden Seura.

Richards, Ivor Armstrong 1965 [1936]. The Philosophy of Rhetoric. New York: Oxford University Press.

Roos, Eduard 1976. Eesti muistsed liittüvelised ja tuletuslikud isikunimed. - Keel, mida me uurime. Koost Mart Mäger. Tallinn: Valgus, 120-130.

Rätsep, Huno 1979. Eesti keele ajalooline morfoloogia II. Tartu Riiklik Ülikool. Tartu.

Rätsep, Huno 2002. Sõnaloo raamat. Tartu: Ilmamaa.

Silvet, Johannes 1990. Inglise-eesti sõnaraamat, II. 4. trükk. Tallinn: Valgus.

Sinha, Chris 1999. Grounding, mapping and acts of meaning. - Cognitive Linguistics: Foundations, Scope and Methodology. Ed. by Theo Janssen, Gisela Redeker. Berlin, New York: Mouton de Gruyter, 223-255.

Sinha, Chris, Kristine Jensen de López 2000. Language, culture and the embodiment of spatial cognition. - Cognitive Linguistics 11, 1/2, 17-41.

Sutrop, Urmas 2004. Eesti keele maailmapildist: meel, hing ja vaim. - Mäetagused 24. Hüperajakiri. Toim Mare Kõiva, Andres Kuperjanov. EKM folkloristika osakonna rahvausundi ja meedia töörühm. MTÜ Eesti Folkloori Instituut. Tartu, 99-108.

Svorou, Soteria 1993. The Grammar of Space. Typological Studies in Language 25. Amsterdam/Philadelphia: John Benjamins Publishing Company.

Sweetser, Eve E. 1995. From Etymology to Pragmatics. Metaphorical and Cultural Aspects of Semantic Structure. Cambridge Studies in Linguistics 54. Cambridge: Cambridge University Press.

Tenjes, Silvi 2002a. Žestid keskajal. - Akadeemia 1, 48-69.

Tenjes, Silvi 2002b. Keelemudel. - Tähendusepüüdja. Pühendusteos professor Haldur Õimu 6o. sünnipäevaks 22. jaanuaril 2002. Toim Renate Pajusalu, Tiit Hennoste. Tartu Ülikooli üldkeeleteaduse õppetooli toimetised 3. Tartu: Tartu Ülikooli Kirjastus, 304-311.

Tenjes, Silvi 2003a. Gestures and spatial relationships in Estonian. - Gestures. Meaning and Use (Proceedings). Ed. by Monica Rector, Isabella Poggi, Nadine Trigo. Oporto: Ediçōes Universidade Fernando Pessoa, 169-173.

Tenjes, Silvi 2003b. Cognitive linguistics: its origins and how to recognize it. - Encounters: Linguistic and Cultural-Psychological Aspects of Communicative Processes. Ed. by Krista Vogelberg, Ene-Reet Soovik. Cultural Studies Series No. 3. University of Tartu. Tartu: Tartu University Press, 185-205.

Tenjes, Silvi 2004. Communicative aspects in conversation: gesture, co-verb and metaphor. - Defining Englishness. Ed. by Pilvi Rajamäe, Krista Vogelberg. Cultural Studies Series No 5. The Estonian Centre for British Studies, University of Tartu. Tartu: Tartu University Press, 139-148.

Veinberga, Mâra 1975. Ühiseid 'käsi' ja 'jalg’ sõnadega fraseologisme eesti ja läti keeles. Fenno-ugristica 1. Tartu Riikliku Ülikooli toimetised. Vihik 344. Tartu Riiklik Ülikool. Tartu, 341-354.

Õim, Asta 2000. Fraseoloogiasõnaraamat. Teine, täiendatud ja parandatud trükk. Tallinn: Eesti Keele Sihtasutus. 


\section{Kaudviited}

Anttila, Raimo 1974. Allomorfien semiotiikkaa. - Virittäjä 78, 331-338.

Donner, Otto 1884. Über den Einfluss des Litauischen auf die finnischen Sprachen. Techmers Internationale Zeitschrift für allgemeine Sprachwissenschaft I. LeipzigHeilborn, 1884, 257- 271.

Elman, J.; Bates, E.; Johnson, M.; Karmiloff-Smith, A. 1996. Rethinking innateness: a connectionist perspective on development. Cambridge, MA: MIT Press.

Endzelīns, Jānis = Эндзелин И. 1906. Латышские предлоги II. Юрьев.

Gopnik, Alison; Meltzoff, Andrew N. 1997. Words, thoughts, and theories. Cambridge, Mass.: Bradford, MIT Press.

Pinker, Steven 1994. The language instinct. How the mind creates language. New York: William Morrow.

Thomsen, Vilhelm 1890. Berøringer mellem de finske og de baltiske (litauisk-lettiske) Sprog. København.

Tomasello, Michael 1995. Introduction: A Cognitive Functional Perspective on Language Structure. - The New Psychology of Language. Cognitive and Functional Approaches to Language Structure. Ed by Michael Tomasello. New York, etc.: Lawrence Erlbaum Associates, vii-1. 


\section{MECHANISIMS AND POSSIBILITIES \\ OF SPATIAL LANGUAGE TO EXPRESS \\ THE CONCEPT OF HAND IN ESTONIAN}

\section{Silvi Tenjes}

The present paper will focus on the variation in Estonian expressions containing $k a ̈ s i$ 'hand; arm' in the Estonian cultural space. The aim is to study Estonian idiomatic expressions and phrasal verbs where käsi occurs as the main word in order to set out the represented spatial relations and to show how the metaphorical projection has been effected and which local cases are represented.

The paper falls within the theoretical framework of Levinson's approach (cf. Levinson 2000, 2001), Sinha's treatment of the human capacity for symbolization, his cultural-cognitive schematization, and human biological and cultural development (Sinha, Jensen de López 2000) as well as Lakoff and Johnson's theory of metaphors (1980). The paper will also look at the grammaticalization of meaning in connection with locative expressions that include the word $k a ̈ s i$. The article provides an overview of previous research on somatic vocabulary and points out the link between the contemporary and earlier views.

Linguistic expressions reveal a dynamic and flexible development. The article deals with the following principles in semantic change: spatial relations, anthropomorphism, grammaticalization, and metaphorization as part of a broader trend from the physical to the mental. Thus, the Estonian expressions containing the word käsi enable us to monitor a certain process of sociocultural stratification evidenced by the various fields of use of the hand that have, with the passage of time, been reified as layers in language. Käsi is also an actor in the grammaticalization process. Such a change in its turn reveals the dynamism of meaning.

Keywords: cognitive linguistics, semantics, metaphorization, space grammar, language and culture, Estonian

Silvi Tenjes (1958) on lõpetanud Tartu Ülikooli filoloogiateaduskonna eesti keele ja kirjanduse erialal eesti keele eriharu. Kaitses Tartu Ülikoolis magistrikraadi üldkeeleteaduse erialal 1995. a ning filosoofiadoktori kraadi üldkeeleteaduse erialal 2001. a. Alates 2004. a töötab Tartu Ülikooli eesti ja soome-ugri keeleteaduse osakonna eesti keele (võõrkeelena) õppetooli dotsendina. On uurinud käežestide seoseid keele ja kommunikatsiooniga, kognitiivset lingvistikat ja tähendusmuutuste mehhanisme ruumimõistete kujunemisel. Huvitub kognitiiv-funktsionaalsest keeleteadusest (tähendusmuutuste kujunemisest, tähendusest ja grammatiseerumisest, metaforisatsioonist ja ruumi mõistestamisest) ning keele seostest kultuuri ja bioloogiaga. Silvi.Tenjes@ut.ee 